\title{
Cikkismertetés: Hogyan lehet legyőzni a félelmet és a szorongást?
}

\section{Article review: How to overcome fear and anxiety?}

\author{
Ismertető: $\quad$ Szigeti Ágotai $\bowtie$ \\ Ismertetett cikk: Mental Health Foundation (2020) How to overcome fear and anxiety (booklet) \\ Mental Health Foundation Registered Charity No. England 801130
}

Beküldve: $\quad$ 2021. 01. 12.

Doi: $\quad$ 10.24365/ef.v62i1.686

Kulcsszavak: félelem; szorongás; szorongás oldása

Keywords: fear; anxiety; anxiety relief

A félelem az egyik legerősebb érzelem, mely nagyon erős hatással van az emberi elmére és a testre. Ha vészhelyzetbe kerülünk, pl. tűz van, vagy megtámadnak bennünket, a félelem erős válaszreakciót képes kiváltani bennünk. Ez akkor is érvényes, ha olyan, kevésbé veszélyes eseményekkel szembesülünk, mint például a vizsgák, nyilvános beszéd, új munkahely, randevú vagy akár egy buli.

A félelem és a szorongás tarthat rövid ideig, ami majd elmúlik, de lehet sokkal tartósabb is. Bizonyos esetekben kihat az egész életünkre. Befolyásolhatja mindennapi életvitelünket, evési, alvási szokásainkat, a koncentrációs képességünket.

$\mathrm{Az}$, hogy mitől félünk, $s$ hogyan viselkedünk adott helyzetben, személyenként változhat. Amikor megijedünk, vagy komolyan szorongunk, elménk és testünk nagyon gyorsan működik. Előfordulhat heves szívdobogás, izzadás, szédülés, szájszáradás, izomfeszülés, koncentrációs nehézségek egyaránt.

Annak oka, hogy így érezzük magunkat, mikor nincs is valódi veszély, a múltban keresendő. $\mathrm{Az}$ ősembereknek szükségük volt arra az életben maradáshoz, hogy gyorsan reagáljanak vészhelyzetekben. A mai modern életünkben ilyen fenyegetésekkel alig találkozunk, mégis elménk és testünk továbbra is ugyanúgy múködik, mint korai őseinké, és ugyanúgy reagálunk modern aggodalmainkra.
A szorongás bármilyen képzelt vagy valódi észlelt fenyegetésre beindulhat. Vannak olyanok is, akik állandóan szorongást éreznek, különösebb indok nélkül. Ha valaki hosszú ideje folyamatosan szorong, vagy úgy érzi, hogy a félelmei teljesen átveszik az élete felett az irányítást, akkor célszerű orvosi segítséget kérni a probléma megoldására.

Fontos tudni, hogy megtanulhatjuk, miként kell megbirkózni a félelmünkkel, hogy az ne akadályozza az életünket. Számtalan módszer létezik erre. Mindenekelőtt szembe kell nézni a félelmünkkel. Vezethetünk például "félelemnaplót", amiben feljegyezzük, hogy mikor mi történik, amikor félünk. A különböző relaxációs technikák - a meditáció, a tai chi vagy a jóga - segíthetnek az ellazulásban, de jótékony hatású lehet például a masszázs is. Természetesen az elegendő menynyiségű testmozgásra és pihenésre is figyelni kell. Az edzés azért is hasznos, mert koncentrációt igényel, ami segít elvonni a figyelmet a félelmünkről. Érdemes kevesebb alkoholt, és cukros ételt fogyasztani, mert ezek - a túl sok kávé és tea fogyasztásához hasonlóan - növelhetik a szorongásszintet. Akihez közel áll a spiritualitás, vagy a vallás, általuk is kaphat segítséget. Illetve fordulhatunk pszichológushoz, vagy kereshetünk önsegítő csoportokat is a környéken, ahol szintén találhatunk megoldást a félelmeink és szorongásunk kezelésére.

' Békés Megyei Pedagógiai Szakszolgálat, Szeghalom 


\section{TANULSÁGOK A HAZAI SZAKEMBEREK SZÁMÁRA}

Fontos, hogy minden egyes esetben igyekezzünk feltárni a probléma gyökerét, s ha elkerülhetetlen, a gyógyszeres kezelést az egyéb terápiás kezelésekkel vagy támogatással kombinálva alkalmazzuk. Számtalan módszer létezik a félelem és szorongás oldására. Minden embert hozzá kell segíteni a számára optimális, neki való megoldás megtalálásához. 